\title{
Pythium Root Rot and Growth Responses of Organically Grown Geranium Plants to Beneficial Microorganisms
}

\author{
Valérie Gravel ${ }^{1}$, Claudine Ménard, and Martine Dorais \\ Agriculture and Agri-Food Canada, Centre de recherche en horticulture, \\ Pavillon Envirotron Local 1116, Université Laval, Québec, G1V 0A6, Canada
}

Additional index words. Pelargonium, organic fertilization, hen manure, Pythium ultimum, Trichoderma, Pseudomonas

\begin{abstract}
Pythium root rot, caused by Pythium ultimum, is responsible for important losses in geranium plant production, mainly as a result of the decrease in the plant overall quality. An organic production system for geranium plants based on fertilization using a filtered suspension of dehydrated hen manure was compared with a conventional fertilization system to evaluate their tolerance to root disease. Under typical greenhouse conditions, geranium plants were inoculated with a suspension of Pseudomonas putida, Trichoderma atroviride, a mixture of both or with Trichoderma harzianum, and a commercially available product, Rootshield ${ }^{\circledR}, 1$ and 4 weeks after planting. Four weeks after the first inoculation, Pseudomonas putida and Trichoderma atroviride stimulated plant growth (shoot and root dry weight) compared with the control regardless of the fertilization. The results also showed that the colonization of geranium roots by Pythium spp. was significantly lower for organically grown plants for all treatments compared with the inoculated control under conventional fertilization. Inoculation with $T$. atroviride under conventional fertilization was the only treatment that did not significantly reduce root colonization by Pythium spp. compared with the conventional control. For both organically and conventionally grown plants, the coinoculation with both $P$. putida and $T$. atroviride resulted in the weakest colonization of roots by the pathogen. The inoculation of $P$. putida, $T$. atroviride, and the mixture of the bacterium and the fungus also significantly increased the fresh and dry weight of roots regardless of the fertilization used. All microorganism treatments in conventionally grown plants significantly increased the fresh and dry weight of the shoot compared with the control.
\end{abstract}

Growing concerns over the protection of the environment is now widespread, especially in the field of agriculture. Consumers are progressively seeking quality produce grown under systems respecting the increasingly restrictive environmental guidelines. In this context, ornamental plant growers should also aspire to achieve a more sustainable production system. Organic amendments of diverse origin such as composts or manure are considered a good source of nutrients and are often used as the main source of fertilization in container-grown organic crops (Raviv et al., 2005). The use of extracts from such organic materials was therefore thought to be an easier way to substitute a conventional production system with an organic ornamental crop such as geranium.

In addition to the potential environmental benefits attached to the use of organic amendments, organic fertilization could also be viewed as a preventive method to control soilborne plant pathogens (Hoitink and Fahy,

Received for publication 18 Mar. 2009. Accepted for publication 3 June 2009.

${ }^{1}$ To whom reprint requests should be addressed; e-mail valerie.gravel@agr.gc.ca.
1986; Raviv, 2008; Raviv et al., 2005). The effectiveness of the use of organic amendments such as composts of diverse origin in the suppression of plant diseases has widely been described in the literature (Chen et al., 1987; Cronin et al., 1996; Hadar and Mandelbaum, 1986; Lumsden et al., 1983; Zhang et al., 1996). Considering that geranium plants are susceptible to root diseases caused by a multitude of pathogens, including numerous Pythium species such as $P$. splendens (Griffin, 1972), P. ultimum (Desilets et al., 1994), and $P$. irregulare (Moorman et al., 2002), the use of extracts from organic materials may prevent losses resulting from such diseases. Moreover, the use of organic amendments for fertilization and to prevent root diseases is also compatible with the inoculation of beneficial rhizosphere microorganisms such as biological control agents or plant growth-promoting microorganisms and would likely lead to an improved repressive effect (Avis et al., 2008).

The objectives of this study were therefore 1) to compare, in terms of plant growth, an organic production system based on dehydrated hen manure extracts for geranium plants to a conventional growing system; and 2) to evaluate the effect of an organic fertilization on the development of Pythium root rot of geranium plants inoculated or not with beneficial microorganisms.

\section{Materials and Methods}

Plant material. Seeds of Pelargonium hybrid cultivar "Moulin Rouge" were sown on 15 Mar. 2007 to obtain stock plants. Geranium plants for the experiment were propagated by cuttings on 1 Aug. 2007. Cuttings were placed in vermiculite in a mist chamber to stimulate root development. On 22 Aug. 2007, uniform cuttings (shoot and root development) were planted in $15-\mathrm{cm}$ plastic pots containing PRO-MIX BX Professional (Premier Tech, Rivière-du-Loup, Québec, Canada), a peat-based growing medium. Pots were then placed in the greenhouse for 1 week before the start of the experiment to assure that the cuttings were developing normally. Growing conditions remained constant during the course of the experiment: temperatures of $22{ }^{\circ} \mathrm{C}$ (day) and $17^{\circ} \mathrm{C}$ (night), $75 \%$ relative humidity, natural daylight supplemented with high-pressure sodium lamps $\left(100 \mu \mathrm{mol} \cdot \mathrm{m}^{-2} \cdot \mathrm{s}^{-1}\right)$ for a $12-\mathrm{h}$ photoperiod, and no $\mathrm{CO}_{2}$ enrichment.

Plant fertilization. Geranium plants received either a conventional or an organic fertilization. Plants were fertilized three times a week with $100 \mathrm{~mL}$ of their respective nutrient solution. The conventional fertilization consisted of a nutrient solution containing $200 \mathrm{ppm}$ of nitrogen (electrical conductivity of $1.5 \mathrm{mS} \cdot \mathrm{cm}^{-1}$ ) and made with $2 \mathrm{~g} \cdot \mathrm{L}^{-1}$ of $10-52-10\left(\mathrm{~N}-\mathrm{P}_{2} \mathrm{O}_{5}-\mathrm{K}_{2} \mathrm{O}\right.$; PlantProd, Laval, Québec, Canada) for the first week and $1 \mathrm{~g} \cdot \mathrm{L}^{-1}$ of $20-8-20\left(\mathrm{~N}-\mathrm{P}_{2} \mathrm{O}_{5}-\mathrm{K}_{2} \mathrm{O}\right.$; Plant-Prod) for the rest of the experiment. The organic fertilization was done using a nutrient solution consisting of a filtered extract of dehydrated and pelleted hen manure. To make the suspension, $0.5 \mathrm{~kg}$ of 8-2-2 $\left(\mathrm{N}-\mathrm{P}_{2} \mathrm{O}_{5}-\mathrm{K}_{2} \mathrm{O}\right)$ and $0.5 \mathrm{~kg}$ of 7-3-9 $\left(\mathrm{N}-\mathrm{P}_{2} \mathrm{O}_{5}-\mathrm{K}_{2} \mathrm{O}\right)$ (Acti-sol Inc., St-Wenceslas, Québec, Canada) were placed in $12 \mathrm{~L}$ of water for $3 \mathrm{~h}$. The solution was mixed every hour and was then filtered through a cotton material. A fresh extract was made every time plants needed to be fertilized. The solution was diluted $(1: 10)$ to obtain an electric conductivity of $2.1 \mathrm{mS} \cdot \mathrm{cm}$. According to preliminary results, the final organic solution contained $200 \mathrm{ppm}$ of nitrogen $\left(\mathrm{NO}_{3}\right.$ and $\left.\mathrm{NH}_{4}\right)($ Table 1). Plants were watered as needed. The experimental design was a splitplot design with six replicates. Main plots (two fertilization treatments) and subplots (five microbial treatments) were randomized within each block. Each experimental unit consisted of three geranium plants except for one of the control plants that consisted of four geranium plants (one plant to be used as an uninoculated control in the final evaluation).

Pathogen. A virulent strain of Pythium ultimum was provided by the laboratory of Dr. Russell Tweddell (Université Laval, Québec, Québec, Canada). The organism was grown on potato dextrose agar (PDA; Difco Laboratories, Becton Dickinson, Sparks, MD) at $24{ }^{\circ} \mathrm{C}$. PDA disks covered with P. ultimum 
Table 1. Composition of the filtered and diluted extract of dehydrated and pelleted hen manure used as the organic nutrient solution and theoretical composition of the conventional nutrient solution.

\begin{tabular}{lcc}
\hline & \multicolumn{2}{c}{ Nutrient solution content (ppm) } \\
\cline { 2 - 3 } & $\begin{array}{c}\text { Organic } \\
\text { solution }^{z}\end{array}$ & $\begin{array}{c}\text { Conventional } \\
\text { solution }^{\mathrm{y}}\end{array}$ \\
\hline $\mathrm{NO}_{3}$ & 193.2 & $200^{\mathrm{x}}$ \\
$\mathrm{NH}_{4}$ & 6.51 & \\
Phosphorus & 7.31 & 34.88 \\
Potassium & 22.80 & 166.02 \\
Calcium & 3.95 & \\
Magnesium & 1.65 & 1.5 \\
$\mathrm{Chlorine}_{\mathrm{SO}_{4}}$ & 84.32 & \\
$\mathrm{Na}$ & 87.6 & \\
$\mathrm{Zinc}$ & 15.5 & \\
Manganese & $<.25$ & 0.5 \\
Copper & $<0.02$ & 0.5 \\
Iron & 0.22 & 0.5 \\
\hline
\end{tabular}

${ }^{z}$ The organic nutrient solution was sampled and analyzed right after the filtration and the dilution of the hen manure extract.

${ }^{\mathrm{y}}$ The conventional nutrient solution was prepared with $1 \mathrm{~g} \cdot \mathrm{L}^{-1}$ of $20-8-20$.

${ }^{\mathrm{x}}$ Total nitrogen.

mycelium conserved in sterile distilled water at $24{ }^{\circ} \mathrm{C}$ served as stock cultures. Considering that, at room temperature, zoospores are not produced by $P$. ultimum (van der PlaatsNiterink, 1981), the propagule suspension of $P$. ultimum consisted of hyphae and oospores. The propagule suspension was prepared from liquid cultures (250-mL flasks) containing $100 \mathrm{~mL}$ of potato dextrose broth (Difco Laboratories) incubated on a rotary shaker (150 rev/min) at $24^{\circ} \mathrm{C}$ for 1 week. PDA disks covered with actively growing mycelium of $P$. ultimum were used to inoculate the flasks.

Beneficial microorganisms. The bacterium and fungus tested in this study were isolated from the rhizosphere of tomato plants (Gravel et al., 2005). The bacterium tested was Pseudomonas putida (Trevisan) Migula Subgroup B Strain 1 and the fungus tested was Trichoderma atroviride Karsten. The bacterium was grown on tryptic soy agar (Sigma-Aldrich, Mississauga, Ontario, Canada) and stock cultures were kept in $80 \%$ glycerol at $-80{ }^{\circ} \mathrm{C}$. Bacterial suspensions were prepared in a $500-\mathrm{mL}$ flask containing $250 \mathrm{~mL}$ of tryptic soy broth (TSB; SigmaAldrich). Flasks were inoculated with $1 \mathrm{~mL}$ of an overnight culture of the bacterium grown in TSB. Flasks were incubated on a rotary shaker $(150 \mathrm{rev} / \mathrm{min})$ at $24^{\circ} \mathrm{C}$ for $24 \mathrm{~h}$. Bacterial cells were removed by centrifugation (4000 g, $10 \mathrm{~min}$ ), resuspended in a phosphate buffer $(0.1 \mathrm{M})$, and diluted to $4 \times$ $10^{7} \mathrm{bacteria} / \mathrm{mL}$. The fungus was grown on PDA (Difco Laboratories) and stock cultures were freeze-dried and kept at $-20{ }^{\circ} \mathrm{C}$. Spore suspensions were prepared by scraping the surface of a 2-week-old mycelium grown on PDA using a glass rod. The spore suspension was adjusted by dilution with a phosphate buffer $(0.1 \mathrm{M})$ to $4 \times 10^{7}$ spores $/ \mathrm{mL}$ based on hemacytometer counts. Rootshield ${ }^{\circledR}$ (Trichoderma harzianum Rifai strain KRL-AG2; BioWorks Inc., Geneva, NY) suspension was prepared according to the recommended application rate of the product $\left(0.75 \mathrm{~g} \cdot \mathrm{L}^{-1}\right.$ of phosphate buffer).

Plant inoculation. Each geranium plant received by drenching $50 \mathrm{~mL}$ of one of the following treatments: a suspension of Rootshield $^{\circledR}$, of P. putida, of T. atroviride, or a mixture of $P$. putida and $T$. atroviride. Control plants received $50 \mathrm{~mL}$ of the phosphate buffer $(0.1 \mathrm{M})$. Plants were inoculated 1 week after planting and 4 weeks later.

Evaluation of plant growth and development. Plant growth was evaluated 4 and 9 weeks after planting on one plant per experimental unit. The number of leaves per plant was counted and the total leaf area was measured using a LI-3100 area meter (LICOR Inc., Lincoln, NE). The fresh and dry weight of both the shoot and the roots were then measured. Flower production (number of flowers) was determined 8 and 12 weeks after planting.

$\mathrm{CO}_{2}$ emission from the growing medium. A 35-g sample of the growing medium was collected from each pot after the evaluation of biomass was completed and placed in a petri dish. Fifteen milliliters of a glucose solution (33.3 g. $\left.\mathrm{L}^{-1}\right)$ was added and mixed thoroughly with the sample to activate the microorganisms present in the growing medium. Samples were incubated at $23{ }^{\circ} \mathrm{C}$ for $24 \mathrm{~h}$ after which the $\mathrm{CO}_{2}$ efflux emitting from the sample was measured using a $\mathrm{CO}_{2}$ flux chamber (Li-6400-09; LI-COR Inc.). The results were expressed in $\mu$ mol $\mathrm{CO}_{2} /$ $\mathrm{m}^{-2} \cdot \mathrm{s}^{-1}$.

Evaluation of Pythium infection on plant growth and root colonization by the pathogen. Eight weeks after planting, one plant per experimental unit was inoculated with 50 $\mathrm{mL}$ of a propagule suspension of $P$. ultimum $\left(1 \times 10^{6}\right.$ propagules $\left./ \mathrm{mL}\right)$. The 12 remaining control plants (one plant per main plot) received $50 \mathrm{~mL}$ of water. Four weeks later (12 weeks after planting), biomass, as an indicator of plant growth and development, was evaluated for three blocks as described previously. The other three blocks were used to evaluate root colonization by $P$. ultimum according to the method described by Chérif et al. (1997). Briefly, $3 \mathrm{~g}$ of geranium roots were rinsed thoroughly and blended in 100 $\mathrm{mL}$ of distilled water. Successive dilutions $1,1 / 10,1 / 100$, and $1 / 1000$ were made and $200 \mu \mathrm{L}$ of each dilution were plated on a corn meal agar, a Pythium-selective medium (Jeffers and Martin, 1986). Three replicates of three plates were made for each dilution. Pythium colonies were counted after $72 \mathrm{~h}$ of incubation in the dark at $24{ }^{\circ} \mathrm{C}$. Results were expressed as number of propagules per gram of fresh roots.

Statistical analyses. The effects of fertilization, microbial inoculation, and the interaction of these fixed effects on plant growth, $\mathrm{CO}_{2}$ effluxes, and Pythium colonization were analyzed using the SAS Mixed Models procedure (SAS Institute, Cary, NC) with replicates as random effects. When significant $(P \leq 0.05)$, means were compared by the Tukey's multiple range test.

\section{Results}

Evaluation of plant growth and development. After 4 weeks after plant inoculation with beneficial microorganisms, regardless of the fertilization used, total leaf area was not significantly different for plants inoculated with $P$. putida, $T$. atroviride, or the mixture of both compared with the control but $16 \%$ higher than plants treated with $T$. harzianum (Table 2). The mean area per leaf was significantly higher $(9.3 \%)$ for organically grown plants (Table 2). Regardless of the fertilization treatment, the fresh and dry weight of the shoot was on average $9.9 \%$ and $10.4 \%$ higher $(P \leq 0.05)$, respectively, for plants treated with $P$. putida, T. atroviride, or the mixture of both compared with the control (Table 2). The fresh and dry weights of the roots were significantly higher $(4.5 \%$ and $32 \%$ to $70 \%$, respectively) for plants treated with $P$. putida, T. atroviride, or the mixture of both compared with the control (Table 2). Results for the plants treated with T. harzianum showed root weights similar to the control (Table 2).

After 8 weeks after the initial inoculation or 4 weeks after the second inoculation, no significant difference was observed between treatments except for the mean area per leaf, which was $12 \%$ higher $(P \leq 0.05)$ for plants grown under an organic fertilization. Overall, the average value for the mean total leaf area was $1271.4 \pm 64.7 \mathrm{~cm}^{2}$. Weights of the shoot were similar between treatments with average values of $113.9 \pm 5.4 \mathrm{~g}$ (fresh) and $13.6 \pm$ $0.7 \mathrm{~g}$ (dry). Similar results were observed for the roots with average values of $12.1 \pm 1.5 \mathrm{~g}$ (fresh) and $1.7 \pm 0.2 \mathrm{~g}$ (dry).

$\mathrm{CO}_{2}$ efflux from the growing medium. $\mathrm{CO}_{2}$ emission 4 weeks after the initial inoculation with the beneficial microorganisms was four times higher $(P \leq 0.05)$ for organically grown plants compared with the conventionally grown ones (Table 3). The same tendency was also observed after 8 and 12 weeks after the inoculation of plants. After 8 weeks, conventionally grown plants treated with beneficial microorganisms showed lower $\mathrm{CO}_{2}$ emission compared with the conventional control (Table 3 ). Organically grown plants treated with the mixture of $P$. putida and $T$. atroviride had significantly lower $\mathrm{CO}_{2}$ emission compared with other organically grown plants (Table 3). After 12 weeks, $\mathrm{CO}_{2}$ emission was generally lower for organically grown plants compared with the measurement taken 4 weeks prior, but was still significantly higher than in the conventional treatment (Table 3).

Evaluation of the effect of Pythium infection on plant growth and root colonization by the pathogen. After 4 weeks after inoculation with P. ultimum (12 weeks after the first inoculation with the beneficial microorganisms), the total leaf area was significantly lower for the conventional $P$. ultimum-inoculated control compared with all other treatments (Table 4), whereas the organic P. ultimuminoculated control was not significantly different from the organic nor the conventional 
Table 2. Plant biomass and leaf area of geranium plants grown under an organic or a conventional fertilization system (4 weeks after the first inoculation with beneficial microorganisms).

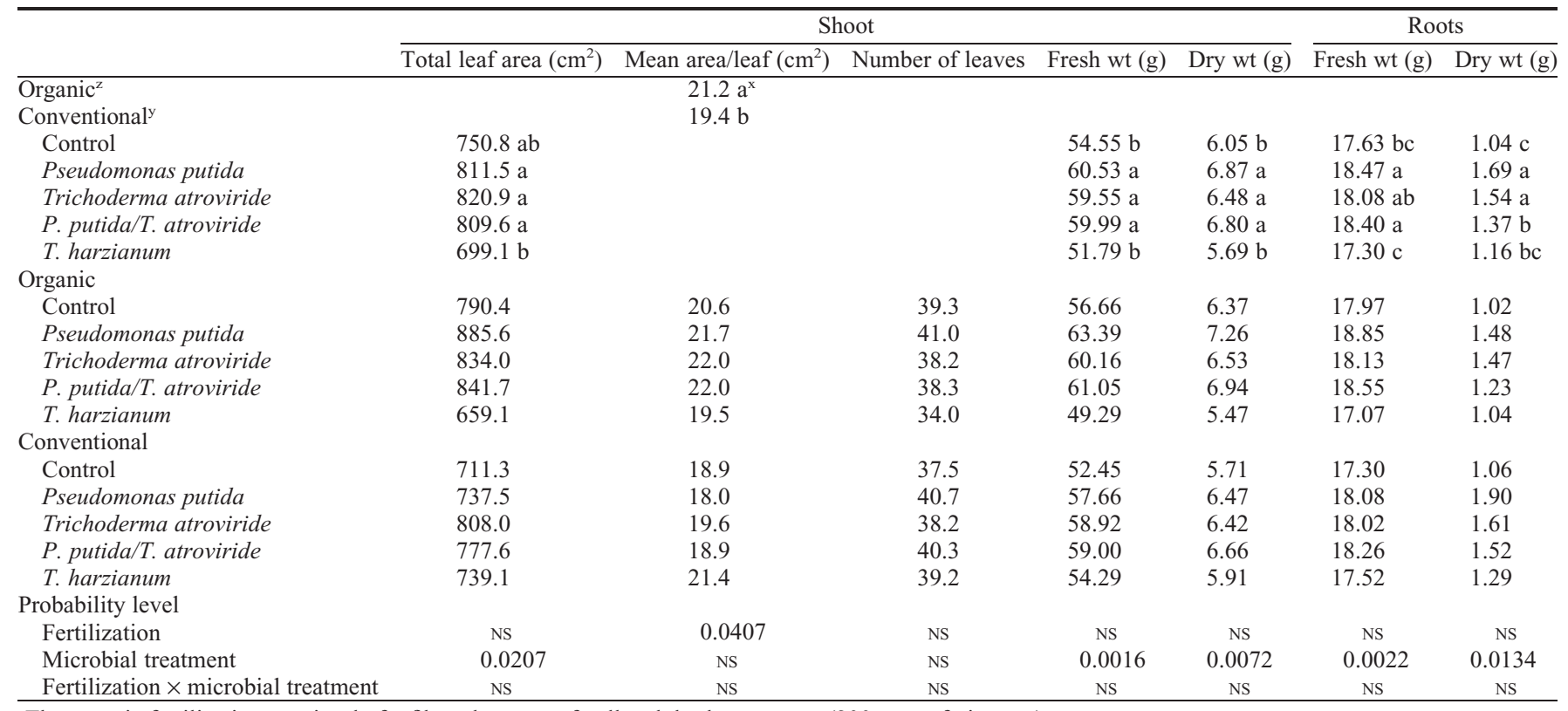

${ }^{\mathrm{z}}$ The organic fertilization consisted of a filtered extract of pelleted dry hen manure (200 ppm of nitrogen).

${ }^{\mathrm{y}}$ The conventional fertilization consisted of a nutritive solution containing $1 \mathrm{~g} \cdot \mathrm{L}^{-1}$ of $20-8-20$.

Data are means of six replicates $(n=6)$.

${ }^{x}$ Within a column, values followed by a similar letter are not significantly different according to Tukey's multiple range test $(P \leq 0.05)$.

NS $=$ Nonsignificant at $\alpha=0.05$.

Table 3. $\mathrm{CO}_{2}$ efflux from the substrate medium of geranium plants grown under an organic or a conventional fertilization system.

\begin{tabular}{|c|c|c|c|}
\hline & \multicolumn{3}{|c|}{$\mathrm{CO}_{2}$ efflux $\left(\mu \mathrm{mol} \mathrm{CO}_{2} / \mathrm{m}^{2} / \mathrm{s}\right)$} \\
\hline & $4 \mathrm{wk}$ & 8 wk & $12 \mathrm{wk}$ \\
\hline Organic $^{z}$ & $14.4 \mathrm{a}^{\mathrm{x}}$ & & \\
\hline Conventionaly & $3.6 \mathrm{~b}$ & & \\
\hline \multicolumn{4}{|l|}{ Organic } \\
\hline Control & 14.8 & $16.2 \mathrm{a}$ & $9.0 \mathrm{a}$ \\
\hline Pseudomonas putida & 16.6 & $16.2 \mathrm{a}$ & $8.3 \mathrm{ab}$ \\
\hline Trichoderma atroviride & 13.1 & $16.1 \mathrm{a}$ & $9.1 \mathrm{a}$ \\
\hline P. putida/T. atroviride & 14.2 & $13.2 \mathrm{~b}$ & $8.4 \mathrm{ab}$ \\
\hline T. harzianum & 13.4 & $15.9 \mathrm{a}$ & $7.2 \mathrm{~b}$ \\
\hline \multicolumn{4}{|l|}{ Conventional } \\
\hline Control & 3.0 & $6.6 \mathrm{c}$ & $2.5 \mathrm{~cd}$ \\
\hline Pseudomonas putida & 3.5 & $1.3 \mathrm{~d}$ & $3.5 \mathrm{c}$ \\
\hline Trichoderma atroviride & 3.2 & $3.6 \mathrm{~d}$ & $2.5 \mathrm{~cd}$ \\
\hline P. putida/T. atroviride & 3.2 & $2.3 \mathrm{~d}$ & $1.3 \mathrm{~d}$ \\
\hline T. harzianum & 4.9 & $1.6 \mathrm{~d}$ & $3.0 \mathrm{~cd}$ \\
\hline \multicolumn{4}{|l|}{ Probability level } \\
\hline Fertilization & 0.0002 & 0.0001 & 0.0001 \\
\hline Microbial treatment & NS & 0.0025 & NS \\
\hline Fertilization $\times$ microbial treatment & NS & 0.0327 & 0.0269 \\
\hline
\end{tabular}

${ }^{\mathrm{z}}$ The organic fertilization consisted of a filtered extract of pelleted dry hen manure (200 ppm of nitrogen).

${ }^{y}$ The conventional fertilization consisted of a nutritive solution containing $1 \mathrm{~g} \cdot \mathrm{L}^{-1}$ of $20-8-20$.

Data are means of six replicates $(\mathrm{n}=6)$.

${ }^{x}$ Within a column, values followed by a similar letter are not significantly different according to Tukey's multiple range test $(P \leq 0.05)$.

NS $=$ Nonsignificant at $\alpha=0.05$.

uninoculated control (Table 4). Similar results were also observed for the fresh weight of the shoot. No significant difference was observed in the dry weight of the shoot among the four controls. Regardless of the microbial treatment, the number of leaves per plant was significantly lower $(8.5 \%)$ for the organically grown plants than conventional ones. In addition, it was also significantly lower for the uninoculated control compared with all other microbial treatments regardless of the fertilization used. For the root fresh weight, values of all treatments were not significantly different from the uninoculated control but were significantly higher from the $P$. ultimum-inoculated control. Root dry weight of $P$. ultimum-inoculated plants with $P$. putida, T. atroviride, or a mix of both was $37 \%$ higher than the $P$. ultimum-inoculated control. However, no significant difference between the $P$. ultimum-inoculated control and noninoculated control was ob- served (Table 4). No significant difference was observed between treatments for flower production (data not shown). Consequently, no quality index was determined nor evaluated.

Conventional uninoculated control plants were not colonized with Pythium spp., whereas the conventional inoculated control showed the highest colonization (388.8 propagules/g of fresh roots) (Table 5). Inoculation with $T$. atroviride under conventional fertilization was the only treatment that did not significantly reduce root colonization by Pythium spp. (Table 5). Colonization of geranium roots by Pythium spp. was significantly lower for organically grown plants for all treatments compared with the inoculated control under conventional fertilization (Table 5). For both organic and conventional fertilization, the coinoculation with T. atroviride and $P$. putida resulted in the lowest root colonization by Pythium spp. (Table 5).

\section{Discussion}

The first objective of this study was to evaluate the potential of an organic fertilization in the production of geranium plants. In the first 8 weeks of the experiment, growth of organically and conventionally grown plants were very similar. The main difference observed between the two growing systems was in the mean area per leaf. This can affect the visual quality of plants produced, although in this case, the difference between the two was relatively small, being at most $2.6 \mathrm{~cm}^{2}$ after 8 weeks of treatment. Flower production and the plant overall quality were unaffected by the fertilization used. This study therefore 
Table 4. Plant biomass and leaf area of geranium plants grown under an organic or a conventional fertilization system and inoculated with Pythium ultimum 4 weeks before evaluation (12 weeks after inoculation with beneficial microorganisms).

\begin{tabular}{|c|c|c|c|c|c|c|c|}
\hline & \multicolumn{5}{|c|}{ Shoot } & \multicolumn{2}{|c|}{ Roots } \\
\hline & Total leaf area $\left(\mathrm{cm}^{2}\right)$ & Mean area/leaf $\left(\mathrm{cm}^{2}\right)$ & Number of leaves & Fresh wt (g) & Dry wt (g) & $\overline{\text { Fresh wt (g) }}$ & Dry wt $(\mathrm{g})$ \\
\hline Organic $^{z}$ & & & $61.6 \mathrm{z}^{\mathrm{v}}$ & & & & \\
\hline Conventional $^{\mathrm{y}}$ & & & $67.3 \mathrm{y}$ & & & & \\
\hline Control $^{\mathrm{x}}$ & & & $53.6 \mathrm{c}$ & & & $13.36 \mathrm{ab}$ & $1.81 \mathrm{ab}$ \\
\hline Control $+^{\mathrm{w}}$ & & & $63.3 \mathrm{~b}$ & & & $8.80 \mathrm{c}$ & $1.70 \mathrm{~b}$ \\
\hline Pseudomonas putida & & & $66.9 \mathrm{ac}$ & & & $15.58 \mathrm{~b}$ & $2.38 \mathrm{a}$ \\
\hline Trichoderma atroviride & & & $67.5 \mathrm{ac}$ & & & $15.08 \mathrm{a}$ & $2.42 \mathrm{a}$ \\
\hline P. putida/T. atroviride & & & $70.4 \mathrm{a}$ & & & $15.44 \mathrm{a}$ & $2.35 \mathrm{a}$ \\
\hline T. harzianum & & & $65.2 \mathrm{ab}$ & & & $12.94 \mathrm{a}$ & $1.89 \mathrm{ab}$ \\
\hline \multicolumn{8}{|l|}{ Organic } \\
\hline Control & $1,386.8 \mathrm{abcd}$ & $21.6 \mathrm{bc}$ & 53.1 & $112.02 \mathrm{~cd}$ & $15.81 \mathrm{bc}$ & 14.03 & 1.51 \\
\hline Control + & $1,258.5 \mathrm{~cd}$ & $20.9 \mathrm{bc}$ & 60.4 & $113.18 \mathrm{~cd}$ & $15.16 \mathrm{bc}$ & 10.82 & 1.35 \\
\hline Pseudomonas putida & $1,649.1 \mathrm{a}$ & $22.9 \mathrm{bc}$ & 67.2 & $134.58 \mathrm{ab}$ & $17.53 \mathrm{ab}$ & 15.14 & 2.20 \\
\hline Trichoderma atroviride & $1,537.6 \mathrm{a}$ & $22.3 \mathrm{abc}$ & 63.5 & $132.54 \mathrm{ab}$ & $17.24 \mathrm{ab}$ & 14.76 & 2.18 \\
\hline P. putida/T. atroviride & $1,621.8 \mathrm{a}$ & $24.7 \mathrm{a}$ & 65.5 & $143.93 \mathrm{a}$ & $18.57 \mathrm{a}$ & 15.08 & 2.17 \\
\hline T. harzianum & $1,292.1 \mathrm{~b}$ & $21.6 \mathrm{bc}$ & 60.1 & $110.41 \mathrm{~d}$ & $14.45 \mathrm{c}$ & 12.78 & 1.68 \\
\hline \multicolumn{8}{|l|}{ Conventional } \\
\hline Control & $1,233.7 \mathrm{~d}$ & $22.8 \mathrm{ab}$ & 54.1 & $114.01 \mathrm{~cd}$ & $16.04 \mathrm{bc}$ & 12.69 & 2.11 \\
\hline Control + & $966.1 \mathrm{e}$ & $17.3 \mathrm{~d}$ & 66.3 & $90.90 \mathrm{e}$ & $10.03 \mathrm{~cd}$ & 6.77 & 2.04 \\
\hline Pseudomonas putida & $1,427.4 \mathrm{ab}$ & $21.5 \mathrm{bc}$ & 66.6 & $126.54 \mathrm{bcd}$ & $17.15 \mathrm{ab}$ & 16.03 & 2.55 \\
\hline Trichoderma atroviride & $1,478.9 \mathrm{ab}$ & $20.8 \mathrm{bc}$ & 71.5 & $119.50 \mathrm{bcd}$ & $16.81 \mathrm{ab}$ & 15.40 & 2.65 \\
\hline P. putida/T. atroviride & $1,501.1 \mathrm{a}$ & $19.9 \mathrm{~cd}$ & 75.3 & $122.38 \mathrm{bcd}$ & $16.98 \mathrm{ab}$ & 15.81 & 2.53 \\
\hline T. harzianum & $1,535.7 \mathrm{a}$ & $21.8 \mathrm{a}$ & 70.3 & $128.94 \mathrm{abc}$ & $18.19 \mathrm{a}$ & 13.10 & 2.10 \\
\hline \multicolumn{8}{|l|}{ Probability level } \\
\hline Fertilization & NS & NS & 0.0407 & NS & NS & NS & NS \\
\hline Microbial treatment & 0.0001 & 0.0398 & 0.0001 & 0.0001 & 0.0001 & 0.0001 & 0.0478 \\
\hline Fertilization $\times$ microbial treatment & 0.0062 & 0.0478 & NS & 0.0062 & 0.0001 & NS & NS \\
\hline
\end{tabular}

zThe organic fertilization consisted of a filtered extract of pelleted dry hen manure (200 ppm of nitrogen).

${ }^{\mathrm{y}}$ The conventional fertilization consisted of a nutritive solution containing $1 \mathrm{~g} \cdot \mathrm{L}^{-1}$ of $20-8-20$.

${ }^{\mathrm{x}}$ Uninoculated control plants.

${ }^{\text {w }} P$. ultimum-inoculated control plants.

Data are means of three replicates $(n=3)$.

'Within a column, values followed by a similar letter are not significantly different according to Tukey's multiple range test $(P \leq 0.05)$.

NS $=$ Nonsignificant at $\alpha=0.05$.

Table 5. Root colonization by Pythium spp. of Pelargonium plants grown under an organic or a conventional fertilization system and inoculated with Pythium ultimum 4 weeks before evaluation.

\begin{tabular}{|c|c|}
\hline & $\begin{array}{l}\text { Root colonization by Pythium spp. } \\
\text { (no. of propagules/g of root) }\end{array}$ \\
\hline \multicolumn{2}{|l|}{ Organic $^{z}$} \\
\hline Control $^{\mathrm{x}}$ & $148.1 \mathrm{~cd}^{\mathrm{v}}$ \\
\hline Control $+{ }^{w}$ & $222.2 \mathrm{bc}$ \\
\hline Pseudomonas putida & $166.6 \mathrm{~cd}$ \\
\hline Trichoderma atroviride & $166.6 \mathrm{~cd}$ \\
\hline P. putida/T. atroviride & 74.0 de \\
\hline T. harzianum & $111.1 \mathrm{~d}$ \\
\hline \multicolumn{2}{|l|}{ Conventional $^{\mathrm{y}}$} \\
\hline Control & $0 \mathrm{e}$ \\
\hline Control + & $388.8 \mathrm{a}$ \\
\hline Pseudomonas putida & $240.7 \mathrm{bc}$ \\
\hline Trichoderma atroviride & $296.3 \mathrm{ab}$ \\
\hline P. putida/T. atroviride & $92.5 \mathrm{de}$ \\
\hline T. harzianum & $129.6 \mathrm{~d}$ \\
\hline \multicolumn{2}{|l|}{ Probability level } \\
\hline Fertilization & 0.0481 \\
\hline Microbial treatment & 0.0001 \\
\hline Fertilization $\times$ microbial treatment & 0.0090 \\
\hline \multicolumn{2}{|c|}{ 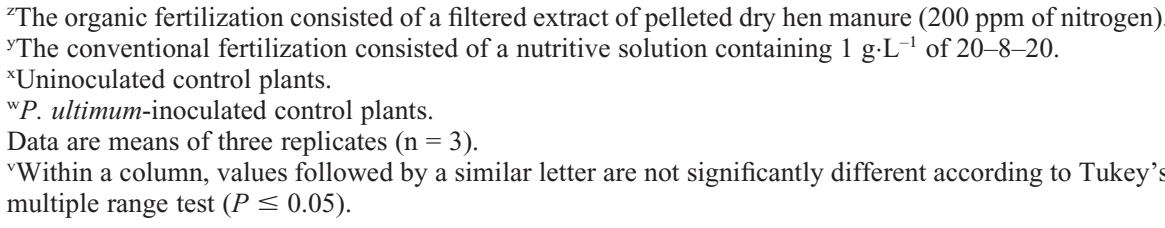 } \\
\hline
\end{tabular}

shows that it is possible to produce highquality organically grown geranium plants by following a similar fertilization schedule as for conventionally grown plants.

Organic fertilization is not as precise as conventional chemical fertilizers. However, the use of compost or manure extract allows for better management of the nutrients readily available for the plant because it does not rely mainly on a turnover of nutrient as is the case with solid organic amendments for soil crop production. It should nonetheless be noted that the use of organic fertilizers is optimized when plants are also inoculated with beneficial microorganisms such as arbuscular mycorrhizal fungi (Perner et al., 2007). In the case of this experiment, results show that inoculation with $P$. putida and $T$. atroviride, two beneficial microorganisms, improved the growth of geranium plants, especially when organic fertilization was used. Considering that the sole source of fertilizer was the manure extract, which was adjusted according to the plant need for available nitrogen, it is most likely that the microorganisms had rather a limited effect on nutrient availability. It is also likely that every time plants were fertilized with the filtered solution, microbial activity in the growing medium was stimulated, which could explain the higher $\mathrm{CO}_{2}$ efflux in the organic treatment. Nevertheless, the use of organic residues, including composted material, should be viewed with caution. Adverse effects on the development (reduced growth index and dry weight) and marketability (lower quality index based on plant height, flower counts, and leaf necrosis) of geranium plants grown using such materials as fertilizers or as part of a growing medium have been reported (Gauthier et al., 1998).

Gladstone and Moorman (1990) demonstrated that losses resulting from Pythium root rot affecting geranium plants are greater when high nitrogen fertilization rates were used. In the case of this experiment, similar nitrogen fertilization rates were used for the conventional and the organic plants to test the effect of the fertilization system itself while 
eliminating the effect of fertilization rates. In the case of this experiment, nitrogen fertilization rates could therefore not explain the effect on Pythium spp. development. Fertilization rates should be sufficient in regard to plant nutrient needs but should not exceed them to avoid overfertilization and the resulting losses of nutrients in the environment.

In addition to their use as a source of nutrients, organic amendments can also play a role in the repression of certain diseases. The use of compost and green manure against pathogens such as Pythium spp. has been described in the literature (Erhart et al., 1999; Hibar et al., 2006; Hoitink and Fahy, 1986; Manici et al., 2004). Suppressiveness of composts has been associated with the reduction of plant pathogens during the composting stages themselves, the presence of antagonist microorganisms in the composts as well as to its chemical and physical factors (Hoitink and Fahy, 1986). Compost has in the past been used as a source of antagonists against $P$. ultimum (Carisse et al., 2003). Craft and Nelson (1996) also concluded that the suppression of Pythium diseases in bentgrass was dependent on microbial properties of compost and of the soil in which it is amended. McKellar and Nelson (2003) showed that the compost-induced suppression of Pythium damping-off of cottonseeds was the result of the increased presence of fatty acid-metabolizing bacteria. Compostamended substrate has been shown to induce a systemic acquired resistance in cucumber against Pythium root rot, perhaps through the increased activity of the microflora (Zhang et al., 1996). The use of compost tea as a treatment against numerous pathogens has also been tested over the years with sometimes mixed results (Scheuerell and Mahaffee, 2006; Sturz et al., 2006). The source and composition of composts used therefore play an important role in the efficacy of the treatments. Our study showed for the first time that the use of hen manure tea as organic fertilizer significantly reduced the root Pythium population $(43 \%$ reduction of the number of propagules per gram of root) of organic $P$. ultimum-inoculated control compared with conventional $P$. ultimum-inoculated plants, suggesting that this organic source of fertilizer may constitute a preventive means against Pythium infection.

On the other hand, the inoculation with specific beneficial microorganisms has been intensely studied to help control infections by pathogenic Pythium species (Carisse et al., 2003; Rankin and Paulitz, 1994). Such biological control is also relevant in organic production in which preventive and curative treatments are limited. In this study, microorganisms already known to reduce Pythium diseases of tomato (Gravel et al., 2006, 2007) were tested to evaluate their effect on the development of Pythium root rot in geranium plants in organic and conventional systems. Our results are a clear example of the pathogen repression benefits that can be exploited from the use of beneficial microorganisms as described by Avis et al. (2008).
Beneficial microorganisms ( $P$. putida and $T$. atroviride) used in this study, alone or in coinoculation, were first shown to have a stimulating effect on geranium plant growth in the early development of the plant (first 4 weeks of the experiment). Such a stimulating effect of those two microorganisms used alone on tomato plants had already been reported (Gravel et al., 2007). In this experiment, these two microorganisms were also shown to reduce the damage caused by $P$. ultimum on geranium shoot and root development. The beneficial effect on plant growth was, however, not observed with $T$. harzianum (Rootshield ${ }^{\circledR}$ ), a commercial biofungicide well known to be effective against soilborne pathogens such as Pythium spp. It should, however, be noted that this strain of $T$. harzianum is not known to stimulate the growth of geranium plants, which is in accordance with results observed in this experiment (Harman, 2000). Nevertheless, this commercial product had a repressive effect on the development of P. ultimum on the roots of the plants.

Soil $\mathrm{CO}_{2}$ efflux is a good indicator of the microbial activity. In this experiment, the $\mathrm{CO}_{2}$ emissions from the substrate samples were $4.9,2.45$, and 3.6 times higher than conventional $\mathrm{CO}_{2}$ efflux control, for a similar root fresh weight $(P>0.05)$, suggesting a higher microbial activity. The filtered hen manure extract used as the source of fertilization in the organic treatment represented a constant source of microorganisms in the growing medium. The microflora was constantly renewed, every $3 \mathrm{~d}$, when plants were fertilized. This probably benefited the development of the plant, especially once $P$. ultimum had been inoculated in the substrate. This is shown in this experiment by the decrease in the root colonization by Pythium spp. under organic fertilization compared with the conventional fertilization. The inoculation with beneficial microorganisms, however, had either a little or no effect on the $\mathrm{CO}_{2}$ effluxes in the organic treatment at each measuring time. The already high microbial activity resulting from the constant inoculation through the dehydrated manure extract and the resulting high microbial competition within the growing medium could explain the observed results. This could also explain, at least partially, the lower root colonization by Pythium spp. in the inoculated organic control compared with the inoculated conventional control. Root colonization by Pythium spp. was, however, observed in the uninoculated organic control indicating that Pythium spp. was naturally present in the organic treatment. Considering that no root colonization was observed in the uninoculated conventional control, the results indicate that the growing medium was not a source of Pythium spp. but that the organic fertilization introduced Pythium propagules. Considering that the selective medium is not specific to pathogenic species of Pythium, but rather to the genus in general, it is possible that nonpathogenic species of Pythium were also detected in the process.
Although fertilization in organic production systems for ornamental potted plants such as geranium needs to be optimized, this study shows that benefits can be obtained from the synergic effect of beneficial microorganisms and the use of organic sources of fertilizers for such a production.

\section{Literature Cited}

Avis, T.J., V. Gravel, H. Antoun, and R.J. Tweddell 2008. Multifaceted beneficial effects of rhizosphere microorganisms on plant health and productivity. Soil Biol. Biochem. 40:17331740 .

Carisse, O., J. Bernier, and N. Benhamou. 2003. Selection of biological agents from composts for control of damping-off of cucumber caused by Pythium ultimum. Can. J. Plant Pathol. 25:258-267.

Chen, W., H.A.J. Hoitink, and A.F. Schmitthenner. 1987. Factors affecting suppression of Pythium damping-off in container media amended with composts. Phytopathology 77:755-760.

Chérif, M., Y. Tirilly, and R.R. Bélanger. 1997. Effect of oxygen concentration on plant growth, lipid peroxidation, and receptivity of tomato roots to Pythium $\mathrm{F}$ under hydroponic conditions. Eur. J. Plant Pathol. 103:255-264.

Craft, C.M. and E.B. Nelson. 1996. Microbial properties of composts that suppress damping-off and root rot of creeping bentgrass caused by Pythium graminicola. Appl. Environ. Microbiol. 62:1550-1557.

Cronin, M.J., D.S. Yohalem, R.F. Harris, and J.H. Andrews. 1996. Putative mechanism and dynamics of inhibition of the apple scab pathogen Venturia inaequalis by compost extracts. Soil Biol. Biochem. 28:1241-1249.

Desilets, H., N. Benhamou, and R.R. Bélanger. 1994. A comparative study of histological and ultrastructural alterations induced by Pythium ultimum or its metabolites on geranium (Pelargonium) roots. Physiol. Mol. Plant Pathol. 45:21-36.

Erhart, E., K. Burian, W. Hartl, and K. Stich. 1999. Suppression of Pythium ultimum by biowaste composts in relation to compost microbial biomass, activity and content of phenolic compounds. Phytopathol. Z. 147:299-305.

Gauthier, F., S. Gagnon, and B. Dansereau. 1998 Incorporation of organic residues to peat-lite substrates for production of impatiens and geraniums. Can. J. Plant Sci. 78:131-138.

Gladstone, L.A. and G.W. Moorman. 1990. Pythium root rot of seedling geraniums associated with high levels of nutrients. HortScience 25:982.

Gravel, V., H. Antoun, and R.J. Tweddell. 2007. Growth stimulation and fruit yield improvement of greenhouse tomato plants by inoculation with Pseudomonas putida or Trichoderma atroviride: Possible role of indole acetic acid (IAA). Soil Biol. Biochem. 39:1968-1977.

Gravel, V., C. Martinez, H. Antoun, and R.J. Tweddell. 2005. Antagonist microorganisms with the ability to control Pythium dampingoff of tomato seeds in rockwool. BioControl 50:771-786

Gravel, V., C. Martinez, H. Antoun, and R.J. Tweddell. 2006. Control of greenhouse tomato root rot Pythium ultimum in hydroponic systems, using plant growth-promoting microorganisms. Can. J. Plant Pathol. 28:475-483.

Griffin, M.J. 1972. Black stem rot (Pythium splendens) of Pelargonium. Plant Pathol. 21:95.

Hadar, Y. and R. Mandelbaum. 1986. Suppression of Pythium aphanidermatum damping-off in 
container media containing composted liquorice roots. Crop Prot. 5:88-92.

Harman, G.E. 2000. Myths and dogmas of biocontrol: Changes in perceptions derived from research on Trichoderma harzianum T-22. Plant Dis. 84:377-393.

Hibar, K., M. Daami-Remadi, H. JabnounKhiareddine, I.E. Akram Znaïdi, and M. El Mahjoub. 2006. Effet des extraits de compost sur la croissance mycéliene et l'agressivité du Fusarium oxysporum f. sp. radicislycopersici. Biotechnol. Agron. Soc. Environ. 10:101-108.

Hoitink, and P.C. Fahy. 1986. Basis for the control of soilborne plant pathogens with composts. Annu. Rev. Phytopathol. 24:93-114.

Jeffers, S.N. and S.B. Martin. 1986. Comparison of two media selective for Phytophthora and Pythium species. Plant Dis. 70:1038-1043.

Lumsden, R.D., J.A. Lewis, and P.D. Millner. 1983. Effect of composted sewage sludge on several soilborne pathogens and diseases. Phytopathology 73:1543-1548.

Manici, L.M., F. Caputo, and V. Babini. 2004. Effect of green manure on Pythium spp. pop- ulation and microbial communities in intensive cropping systems. Plant Soil 263:133-142.

McKellar, M.E. and E.B. Nelson. 2003. Compostinduced suppression of Pythium damping-off is mediated by fatty acid metabolizing seed colonizing microbial communities. Appl. Environ. Microbiol. 69:452-460.

Moorman, G.W., S. Kang, D.M. Geiser, and S.H Kim. 2002. Identification and characterization of Pythium species associated with greenhouse floral crops in Pennsylvania. Plant Dis. 86:1227-1231.

Perner, H., D. Schwarz, C. Bruns, P. McTder, and E. George. 2007. Effect of arbuscular mycorrhizal colonization and two levels of compost supply on nutrient uptake and flowering of Pelargonium plants. Mycorrhiza 17:469-474.

Rankin, L. and T.C. Paulitz. 1994. Evaluation of rhizosphere bacteria for biological control of pythium root rot of greenhouse cucumbers in hydroponic culture. Plant Dis. 78:447-451.

Raviv, M. 2008. The use of compost in growing media as suppressive agent against soil-borne diseases. Acta Hort. 779:39-50.
Raviv, M., Y. Oka, J. Katan, Y. Hadar, A. Yogev, S. Medina, A. Krasnovsky, and H. Ziadna. 2005. High-nitrogen compost as a medium for organic container-grown crops. Bioresour. Technol. 96:419-427.

Scheuerell, S.J. and W.F. Mahaffee. 2006. Variability associated with suppression of gray mold (Botrytis cinerea) on geranium by foliar applications of nonaerated and aerated compost teas. Plant Dis. 90:1201-1208.

Sturz, A.V., D.H. Lynch, R.C. Martin, and A.M. Driscoll. 2006. Influence of compost tea, powdered kelp, and Manzate 75 on bacterialcommunity composition, and antibiosis against Phytophthora infestans in the potato phylloplane. Can. J. Plant Pathol. 28:52-62.

van der Plaats-Niterink, A.J. 1981. Monograph of the genus Pythium. Institute of the Royal Netherlands Academy of Sciences and Letters, Baarn, The Netherlands, pp. 164-167.

Zhang, W., W.A. Dick, and H.A.J. Hoitink. 1996. Compost-induced systemic acquired resistance in cucumber to Pythium root rot and anthracnose. Phytopathology 86:1066-1070. 